DOI: 10.19195/0137-1150.167.38

KATARZYNA ARCISZEWSKA

Uniwersytet Gdański, Polska

\title{
Śmierć i nieśmiertelność — dwa aspekty mitu wampirycznego (na podstawie wybranych utworów rosyjskiej literatury popularnej)
}

Śmierć to najwierniejsza towarzyszka człowieka. Jej powszechność komentuje między innymi rosyjski myśliciel Aleksandr Radiszczew, podkreślając przy tym jej degradujące oddziaływanie:

Смерть есть не что иное, как естественная перемена человеческого состояния. Перемене таковой не токмо причастны люди, но все животные, растения и другие вещества. Смерть на земле объемлет всю жизненную и нежизненную естественность. Знамение ее есть разрушение. Итак, куда бы мы очей своих ни обратили, везде обретаем смерть ${ }^{1}$.

Permanentna obecność śmierci w prywatnej sferze egzystencji jednostki, a także w dyskursie kulturowym nie zmienia faktu, że jest ona, mimo swego uniwersalizmu, ,jednym z [...] najmniej znanych faktów życia ludzkiego" ${ }^{2}$. Postawionego przed zagadką i nieuchronnością śmierci człowieka, niezależnie od epoki i miejsca, w którym żyje, charakteryzuje dążenie do oswojenia myśli o nieuniknionej sytuacji krańcowej, a „potrzeba zrozumienia i wyjaśnienia zjawiska śmierci towarzyszy zarówno wszystkim wierzeniom religijnym, jak i filozofii od najdawniejszych czasów"3.

W rozważaniach o śmierci należy zwrócić uwagę, że niezmienność jej istnienia łączy się ze zmiennością jej obrazu i percepcji. Jak pisze Michel Vovelle, „społeczna historia śmierci jest utkana z mniej lub bardziej powolnych ewolucji,

${ }^{1}$ А. Радищев, О человеке, его смертности и бессмертии, [w:] idem, Сочинения, Москва 1988, http://ruslit.traumlibrary.net/book/radischev-sochinenia/radischev-sochinenia.html\#work005 [dostęp: 12.07.2017].

${ }^{2}$ A. Ostrowska, Śmierć i umieranie, Warszawa 1991, s. 5.

${ }^{3}$ Ibidem, s. 7. 
których ślady nawarstwiły się w pamięci, obrazach i gestach"4. Zainteresowanie śmiercią intensyfikuje się w zależności od ideologicznych uwarunkowań epoki oraz od mentalności uczestników danej kultury ${ }^{5}$. Człowieka Zachodu charakteryzuje lęk przed śmiercią, uzasadniony niemożnością racjonalnego jej poznania "[́́]mierci nie można zdefiniować, ponieważ oznacza ona ostateczną pustkę, nieistnienie [...]. Śmierć jest absolutnym innym bycia, niewyobrażalnym innym, unoszącym się poza zasięgiem komunikacji”’6.

W rosyjskim postrzeganiu śmierci daje się zauważyć postawę naturalnej akceptacji. Jej początków należy upatrywać już w starej Rusi. Nieodczuwanie strachu przed końcem ziemskiej egzystencji wynika z koncepcji śmierci jako nagrody za sprawiedliwe życie ${ }^{7}$. Nawiązują do niej także dwudziestowieczni myśliciele:

należy swoje życie nakierowywać tak, aby śmierć była nie jego zerwaniem, ale zwieńczeniem. Fakt zaś, że człowiek nie zna daty swojej śmierci ma znaczenie o tyle pozytywne, że pobudza to do bycia w ciągłej gotowości do odejścia z tego świata. Śmierć [...] jest zasadą życia. Stanowi ona kryterium, które rozstrzyga, co w życiu było warte przeżycia, a co było bezwartościowe. [...] Śmierć uczy człowieka, aby dokonywał on właściwych wyborów życiowych ${ }^{8}$.

Szczególny stosunek Rosjan do śmierci opisuje Iwan Iljin. Filozof podkreśla szacunek wobec śmierci, dbałość o właściwe jej przyjęcie, poprzedzone oczyszczeniem ciała i ducha:

Смерть может придти внезапно, как несчастный случай, или крадучись, на ложе болезни, или же на поле брани - но никогда нет в русском человеке ничего подобного малодушию, страху, внутреннему разладу, а лишь сосредоточенная забота о христианском отпущении грехов и чистоте тела. Есть древний обычай: русский солдат перед сражением тщательно моется и надевает чистую „смертную рубаху”. И поучительно видеть, как Тургенев, Лев Толстой, Чехов и другие, кто потерял веру, восхищаются и художественно превозносят этот эпический покой, это скромное достоинство, эту метафизическую свободу, с которой русский народ идёт на смерть 9 .

Współcześnie mamy do czynienia z ambiwalentnym stosunkiem do śmierci. $Z$ jednej strony, pragniemy przemilczeć fakt jej istnienia, jej nieuchronność. W tym celu uczestnicy ponowoczesnej rzeczywistości oddają się niespotykanej wcześniej dbałości o zdrowie, dobrą kondycję i wygląd, biorą udział w specyficz-

${ }^{4}$ M. Vovelle, Śmierć w cywilizacji Zachodu, przeł. M. Ochab, Gdańsk 2008, s. 42.

${ }^{5}$ Zob. ibidem; L. V. Thomas, Tworzenie tanatologii, przeł. M. L. Kalinowski, [w:] Wymiary śmierci, wyb. i słowo wstępne S. Rosiek, Gdańsk 2010, s. 18.

${ }^{6}$ Z. Bauman, Śmierć i nieśmiertelność. O wielości strategii życia, przeł. N. Leśniewski, Warszawa 1998, s. 6.

${ }^{7}$ Por. В. Варава, Смерть, [w:] Русская философия. Энииклопедия, red. М. Маслин, Москва 2007, s. 510-511.

${ }^{8}$ A. Sawicki, Rosyjska immortologia. Śmierć i nieśmiertelność $w$ poglądach myślicieli XVIII-XX wieku, Białystok-Kraków 2016, s. 272-273.

${ }^{9}$ И. Ильин, Сущъность и особенность русской культуры, „Пространство и время” 2010, nr 1, s. 203, http://space-time.ru/index.php/space-time/article/view/2226-7271provr_st11.2010.121/389 [dostęp: 12.07.2017]. 
nym spektaklu tworzenia i publicznej prezentacji swego wizerunku. W obawie przed śmiercią staramy się nie myśleć o tym, co ma się zdarzyć w nieokreślonej przyszłości, skupiamy się na teraźniejszości. Z drugiej strony, lękając się śmierci naturalnej, fascynujemy się śmiercią nieoczekiwaną, oglądamy relacje z wypadków, zdarzeń losowych, w których ludzie giną nagle. Tego rodzaju wyjątkowe zainteresowanie śmiercią we współczesnej kulturze Geoffrey Gorer określił mia-

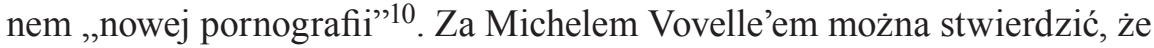

epoka współczesna wyzwoliła wyobraźnię zbiorową z tradycyjnych ram, w jakich była zamknięta, i doprowadziła do rozmnożenia przekazów, w których pośrednio lub bezpośrednio śmierć wpisuje się w wyobrażenia zbiorowe. Swobodnego dyskursu na temat śmierci należy dzisiaj szukać w najrozmaitszych źródłach proponowanych przez media, takich jak piosenka, radio, telewizja, film, komiks czy reklama ${ }^{11}$.

Czytelnicy literatury popularnej chętnie sięgają po gatunki przedstawiające różne aspekty śmierci - kryminał, apokalipsę, opowieść wampiryczną. Obcowanie ze śmiercią w przestrzeni kulturowej można, jak się wydaje, uznać za swoisty, nieświadomy etap przygotowania na jej przyjęcie. W wypadku ostatniego z wymienionych gatunków należy podkreślić szczególny sposób traktowania motywu śmierci, która nie oznacza ostatecznego zakończenia ziemskiej egzystencji, a także motywu nieboszczyka, który w wyniku wampirycznej przemiany jest w stanie, jakkolwiek borykając się z zasadniczymi ograniczeniami, uczestniczyć w kontinuum życia. Stosunek człowieka do zmarłych ,nacechowany jest wieloma emocjami; przejawiają się w nich elementy strachu, niepokoju, czci, miłości, niesmaku, grozy i obrzydzenia" ${ }^{2}$. Potrzeba skumulowania i neutralizacji nieprzyjemnych odczuć towarzyszących ludziom w konfrontacji z nieżywymi uruchamia w wyobraźni zbiorowej proces kreacji potworów ucieleśniających strach przed przekraczaniem granicy pomiędzy życiem a śmiercią. Jednym z nich jest wampir. Pisarze dostrzegają i wykorzystują

ogromny potencjał kryjący się w zastosowaniach fantazmatu wampirycznego w kontekście śmierci i spraw ostatecznych; jest on bowiem na tyle plastyczny i podatny na modyfikacje, że można zawrzeć w nim zarówno wszelkie koncepcje eschatologiczne, jak też pokusić się o zadawanie innych, nieraz równie frapujących, pytań o śmierć i umieranie ${ }^{13}$.

W tradycji i kulturze ludowej krajów słowiańskich pojawiają się liczne istoty o proweniencji i wymowie zbliżonej do wampirycznej (na przykład wilkołaki, strzygi, zmory, południce), jednak „,spośród wielu mniej lub bardziej makabrycz-

${ }^{10}$ G. Gorer, Death, Grief and Mourning, New York 1965, cyt. za: A. Ostrowska, Śmierć i umieranie, s. 11 .

${ }^{11}$ M. Vovelle, Historia ludzi w zwierciadle śmierci, przeł. M. Ochab, [w:] Wymiary śmierci, s. 46.

12 A. Ostrowska, Śmierć i umieranie, s. 20.

${ }^{13}$ M. Wolski, Wampir: wiwisekcja. Wyobrażenia krwiopijcówwe współczesnej kulturze, Wrocław 2014, s. 134. 
nych postaci wampir cieszył się [...] największą chyba popularnością"14. Jest to postać wieloznaczna, ogniskująca w sobie strach żywych przed zmarłymi oraz dająca złudne przeczucie, że to istota obca, potworna, wykreowany Inny, a nie człowiek poddawany jest procesowi biologicznego rozkładu. Literackie ilustracje takiego wizerunku wampira charakteryzują się turpistyczną dosadnością, korespondującą z zamierzonym przekazem symbolu. Pisarze przywołują stałe atrybuty ożywionego nieboszczyka: martwe oczy, bladą twarz, trupi oddech, zapach rozkładającego się ciała czy okrwawione wargi.

W tradycyjnym ujęciu wampir ma bezpośredni i wielopoziomowy związek ze śmiercią. Jest on wszak ożywionym ciałem zmarłego, „wychodzi z grobu, błądzi nocą i wysysa krew ze śpiących, powodując tym samym ich rychłą śmierć"15. Taki obraz wampira funkcjonuje w inspirowanej gotycyzmem literaturze dziewiętnastowiecznej. Najbardziej znanymi kreacjami istot wampirycznych tego czasu w Rosji są bohaterowie utworów Aleksego Tołstoja Rodzina wilkołaka (Семья вурдалака, 1839) і Upiór (Уnырь, 1841). Powielają oni kanon wampirycznych zachowań. W epoce wiary $\mathrm{w}$ istnienie krwiopijców powszechnie twierdzi się, że „po wyjściu z grobów szły one nocą ucałować gwałtownie swoich krewnych lub przyjaciół, którym wysysały krew”, w wyniku czego „ci, których to spotkało, słabli do tego stopnia, iż umierali prawie natychmiast" 16 . W podobny sposób Gorcza, protagonista Rodziny wilkołaka, uśmierca swojego wnuka, rozpoczynając tym samym kontinuum śmierci:

он-то похоронен взаправду, и в сердце - кол! Но он у Георгиева сына высосал кровь. Мальчик и вернулся ночью, плакал под дверью, ему, мол, холодно и домой хочется. У дуры-матери, хоть она сама и его хоронила, не хватила духа прогнать мальчика на кладбище, - она и впустила его. Тут он набросился на нее и высосал у нее всю кровь. Когда ее тоже похоронили, она вернулась и высосала кровь у меньшего мальчика, потом - у мужа, а потом у деверя. Всем - один конец ${ }^{17}$.

Tołstoj odwołuje się tu do motywu wampira „zawsze łączonego z epidemiami"”18: dżumą, cholerą i innymi chorobami, dziesiątkującymi ludność. Interpretacja wampiryzmu jako źródła zarazy nieobca jest też twórcom i odbiorcom w XX i XXI wieku, co jest pokłosiem pojawienia się nowych schorzeń rozprzestrzeniających się przez zarażoną krew, wśród których najbardziej „wampirycznym” wydaje się AIDS $^{19}$, a wywołujący go wirus to, podobnie jak ludowa interpretacja

${ }^{14}$ M. Bradke, Wstęp, [w:] Pokój na wieży. Opowieści wampiryczne, wyb. i oprac. M. Bradke, Wrocław-Warszawa-Kraków 1991, s. 23.

15 J. P. Roux, Krew. Mity, symbole, rzeczywistość, przeł. M. Chrobak, Kraków 2013, s. 291.

16 J. C. de Plancy, Stownik wiedzy tajemnej, przeł. M. Karpowicz, Warszawa-Kraków 1993, s. 190.

17 А. Толстой, Семья вурдалака, http://detectivebooks.ru/book/6563755/?page=6 [dostęp: 11.01.2018].

18 M. Janion, Wampir. Biografia symboliczna, Gdańsk 2002, s. 49.

19 Analogie między wampirem a wirusem wywołującym choroby krwi dostrzega na przykład Monika Sznajderman; zob. eadem, Zaraza, Mitologia dżumy, cholery i AIDS, Warszawa 1994. 
wampira, „kwintesencja nieczystości, kwintesencja czegoś zarażającego, kalającego, brudzącego" 20 .

Wizję wampiryzmu przenoszonego przez krew oraz stosunek seksualny czytelnik znajdzie w powieści Olega Diwowa Nocny obserwator (Ночной смотрящий, 2004). Pisarz mówi o zainfekowanej krwi, wirusie (,Если этот вирус [...] еще не выдохся?! [...] Да ты представь на секундочку, кого она жрет и какая дрянь после этого у нее в крови плавает" 21 ), terapii uśmierzającej wampiryczny instynkt („На транквилизаторах. Дня за два до начала каждого цикла ко мне переселяется доктор и начинает глушить бедную"22), potrzebie wynalezienia szczepionki („Или найти противоядие. Вакцину”23); wpływ zaś wypitej krwi na zmysły wampira porównuje do oszałamiającego działania narkotyku („Миша от крови мгновенно опьянел. [...] Кровь манила и сводила с ума"24), które przez kolejne kryzysy („,очередной кризис" ${ }^{25}$ ) prowadzi do śmierci („Будете и дальше упиваться кровью - значит вам с Катериной осталось всего ничего"26). W ujęciu Diwowa krew, będąca zazwyczaj nośnikiem nadprzyrodzonej mocy wampira, staje się zatem jego zgubą.

$\mathrm{W}$ najnowszych utworach wampirycznych $\mathrm{w}$ związku ze zmianą mentalności człowieka następuje przeniesienie akcentu z wynaturzenia ciała i śmierci fizycznej na dezintegrację psychiki istoty przemienionej. Wampiryzm jako zagrożenie dla umysłu człowieka przedstawia Diwow we wspomnianej powieści, której bohater przestrzega niedawno zainicjowanego wampira przed konsekwencjami nowego stanu. Zmienia się też sposób prezentacji wampirycznej aktywności. Wizerunek współczesnego wampira nie epatuje krwiożerczą brutalnością, wampiryzm rozpatrywany jest jako syndrom nieuleczalnej choroby ${ }^{27}$. Jej objawy i następstwa dotyczą bezpośrednio nosiciela, a nie, jak w dawnych przekazach, ofiar ożywionego zmarłego:

Зимой будет нечто вроде спячки - ты еще сможешь шевелиться и выполнять какую-то работу, самую примитивную. [...] В зимние полнолуния наступят жуткие ломки [...]. С болями по всему телу [...]. К весне окажешься от пережитого малость сумасшедшим. [...] В промежутках между полнолуниями вы будете вести себя как

\footnotetext{
20 Ibidem, s. 118.

21 О. Дивов, Ночной смотрящий, Москва 2008, s. 156.

22 Ibidem, s. 233.

23 Ibidem, s. 240

${ }^{24}$ Ibidem, s. 182.

25 Ibidem, s. 187.

26 Ibidem, s. 190-191.
}

27 O naukowych hipotezach utożsamiających wampiryzm z wybranymi jednostkami chorobowymi, przede wszystkim z porfirią i wścieklizną, zob. M. Janion, Wampir..., s. 68-69; M. T. Załoga, Zachorować na Draculę, „Gazeta Wyborcza” 7.05.2002; M. Pustkowski, Lustracja wampira, ,Polityka” 10.03.2007, http://www.polityka.pl/tygodnikpolityka/nauka/212320,1,lustracja-wampira.read [dostęp: 13.07.2017]; J. Krzyk, Porfiria. Skąd się biora wampiry?, „Gazeta Wyborcza” 17.11.2014, http://wyborcza.pl/alehistoria/1,121681,16968029,Skad_sie_biora_wampiry_. html [dostęp: 13.07.2017]. 
сонные мухи, но это не главное. Вам потребуется все меньше еды. Значит, начнет усыхать, а потом и отмирать кишечник - это сопровождается жуткими болями. [...] Неминуемо сдвинется психика ${ }^{28}$.

Rosyjski pisarz dokonuje reinterpretacji motywu wampira w kontekście jego związku ze śmiercią — z jej ucieleśnienia i sprawcy staje się on jej ofiarą, ponieważ wampiryczna metamorfoza jest zapowiedzią nieuchronnego końca egzystencji („,Пойми, вампир на пике формы - это два-три года максимум”29). Większość bohaterów Nocnego obserwatora zostaje zarażona bez ich wiedzy i zgody, wampira spotyka zatem śmierć nieoczekiwana i nieuchronna, co stawia go w sytuacji ofiar współczesnych chorób cywilizacyjnych, natomiast w opisie finalnego etapu życia wampira autor podkreśla występowanie poprzedzających agonię starczych przypadłości, niedołężności, zmian chorobowych, co można odczytać jako odniesienie do tematu starości, która towarzyszy śmierci w dyskursie kulturowym i socjologicznym. Interpretacja postaci wampira jako istoty chorej usprawiedliwia jej postępowanie oraz zmienia stosunek odbiorców, ponieważ „больной, как правило, не имеет вины и не несет ответственности за последствия своего заболевания. А поэтому не должен вызывать ненависти, даже если его существование угрожает здоровым" ${ }^{30}$.

W kontekście związku wampira z AIDS interesujący jest pomysł autorów powieści Bracia krwi (Кровные братья, 2005) ${ }^{31}$. W ich ujęciu wampir charakteryzuje się nadludzką mocą i niezagrożoną ziemskimi przypadłościami kondycją. Dlatego przeistoczenie człowieka w istotę nieumarłą stanowi we wspomnianym utworze ratunek dla osób śmiertelnie chorych: „Фэриартос ${ }^{32}$ спасли его от неизлечимой болезни, чумы двадцатого века, и теперь он наслаждался новой, как говорил, »загробной«, жизнью" 33 . W ten sposób po raz kolejny wampir wychodzi poza ramy, w jakie zamyka go tradycja. Krwiopijca staje się dobroczyńcą swej dawnej ofiary, choć pobudki jego działania wynikają z zazdrości i tęsknoty za człowieczeństwem i śmiertelnością. W wypowiedzi jednego $\mathrm{z}$ bohaterów powieści wybrzmiewa żal po utracie ludzkiej natury ze wszystkimi jej ułomnościami, które - widziane z dystansu — okazują się paradoksalnie doskonałe w swoich ograniczeniach:

Все мы тоскуем о прежней жизни [...]. И мстим смертным за то, что они так беспечны и свободны, за то, что их жизнь так коротка, за то, что они могут видеть солнце. Поэтому мы превращаем их в себе подобных, чтобы они жили бесконечно и мучились так же, как и мы ${ }^{34}$.

28 О. Дивов, Ночной смотрящий, s. 193-194.

${ }^{29}$ Ibidem, s. 194.

${ }^{30}$ Е. Ковтун, Вампир без страха и упрека: новейшие модификации образа, [w:] Fantastyka rosyjska dawniej i dziś, red. A. Polak, wsp. I. Zawalska, Katowice 2013, s. 40-41.

31 Autorami powieści są Aleksiej Piechow, Jelena Byczkowa i Natalia Turczaninowa.

32 Nazwa jednego z wampirycznych klanów, których przedstawiciele są głównymi bohaterami powieści.

33 А. Пехов, Е. Бычкова, Н. Турчанинова, Кровнье братья, Москва 2011, s. 197.

${ }^{34}$ Ibidem, s. 133. 
Pejoratywny stosunek do wampira-Obcego w ciągu wieków ewoluuje, co w konsekwencji prowadzi do jego rehabilitacji. Odbiorcy kultury na nowo odczytują zakodowany w wampirze przekaz, a samą postać odbierają przez pryzmat refleksji nad jego proweniencją. Jak pisze Jelena Kowtun, ,postać wcześniej traktowana jako bezwarunkowo infernalna coraz częściej spotyka się z traktowaniem pełnym współczucia. Pozytywni bohaterowie zaczęli "wcielać się w role « wampirów"35. W XX wieku człowiek rozumie sytuację wampira - istoty skazanej na samotność, która ,jest poniekąd przybliżaniem się do śmierci" "36. Wzmacnia to jeszcze związek wampira ze śmiercią - najpierw musi umrzeć jako człowiek, a następnie nosi jej piętno, wyciśnięte przez jego status „nieprzynależności”, zawieszenia w przestrzeni pomiędzy życiem a śmiercią, człowiekiem a bestią. Nierozerwalna relacja ze śmiercią, osadzoną w „pozaznaczeniowości” ${ }^{37}$, powoduje, że wampir traci jasno określoną tożsamość i identyfikację, co upodabnia go do uczestnika kultury ponowoczesnej, daremnie dążącego do samookreślenia. Dlatego też wampir przestaje być realnym zagrożeniem, zyskując nową funkcję towarzysza ratującego człowieka przed samotnością (śmiercią społeczną) w świecie zerwanych więzi i zanikających relacji. W interpretacji autorów powieści Bracia krwi jest to układ oparty na obustronnej korzyści. Główny bohater utworu, odczuwający skutki wampirycznej egzystencji, znajduje antidotum na męczącą go samotność w przyjaźni z człowiekiem. Kontakt z poszukującym swojej drogi życiowej nastolatkiem, zagubionym w świecie, separującym się od rodziny i znajomych, budzi w wampirze uśpioną potrzebę przynależności, bliskości:

Почему меня тянет к тебе, крохотный огонек на мосту? Ни тепла от тебя, ни света. Движение руки, и я погашу тебя. Зачем ты мне? Почему мое, давно уже успокоенное, сердце вспоминает, как сладко замирать и взлетать, как приятно волноваться и ждать? ...как хорошо быть человеком, как хорошо... не быть одному... ${ }^{38}$

Natomiast w postawie młodego człowieka, który nie wzdraga się przed przyjaźnią z wampirem, nawet poznawszy jego naturę, widać potrzebę ucieczki od otaczającej go rzeczywistości, pragnienie przekroczenia granicy zwyczajnego, przewidywalnego życia. Wampir utożsamiony jest $\mathrm{w}$ tej sytuacji $\mathrm{z}$ emanacją fantastycznego świata, kreowanego przez wyobraźnię młodego marzyciela przedstawiciela swego pokolenia:

Они постоянно живут в ожидании чуда, даже если сами не понимают этого. Желают видеть себя главным героем истории, происходящей в настоящей жизни. Мечтают стать владельцами личного волшебника, робота, инопланетянина, лепрекона, русалки... вампира. [...] И тут вдруг появляюсь я - воплощение подросткового бреда ${ }^{39}$.

35 Е. Ковтун, Вампир без страха и упрека..., s. 41.

36 A. Sawicki, Rosyjska immortologia..., s. 35.

${ }^{37}$ L. V. Thomas, Trup. Od biologii do antropologii, przeł. K. Kocjan, Łódź 1991, s. 68.

38 А. Пехов, Е. Бычкова, Н. Турчанинова, Кровныле братья, s. 100.

${ }^{39}$ Ibidem, s. 110. 
W obecnych okolicznościach egzystencjalnych człowieka definiuje ,impuls przeżycia" ${ }^{40}$, który stanowi „sedno wszelkiego okrucieństwa, brutalności i znieczulicy" ${ }^{\prime 1}$ w dążeniu do indywidualnego i gatunkowego przetrwania. Śmierć interpretowana jest jako nicość, kres wszelkiej aktywności człowieka. „Horror śmierci jest horrorem pustki, ostatecznej nieobecności, »nie-bycia «"42. Rodzi to potrzebę wypełnienia wyobrażonej próżni, rozbudza pragnienie nieśmiertelności, kontynuacji życia. Adam Sawicki, autor książki Rosyjska immortologia. Śmierć i nieśmiertelność w pogladach myślicieli XVIII-XX wieku, zauważa, że człowieka od zawsze charakteryzuje tęsknota za nieśmiertelnością:

Tęsknota za nieśmiertelnością jest u człowieka czymś poniekąd wrodzonym i wynika z samego charakteru i istoty życia. Najpierw przejawia się w postaci troski o zachowanie swojej cielesności, ale kulminuje w stanięciu oko w oko z realnością zupełnego wygaśnięcia świadomości i przejścia $\mathrm{w}$ taką nieświadomość, a w istocie pustkę, która nie będzie już miała absolutnie żadnej szansy na przebudzenie $\operatorname{się}^{43}$.

Szukając odpowiedzi na pytanie: ,,[s]kąd się bierze w człowieku tęsknota za życiem nieśmiertelnym?"44, Sawicki wspomina o poczuciu ciągłości i kontynuacji bytu ${ }^{45}$ pomimo wiedzy o nieuchronności biologicznego umierania. W poszukiwaniu sposobów eliminacji śmierci wyobraźnia ludzka tworzy wiele projektów. W niektórych z nich, jak w koncepcji rosyjskiego myśliciela Nikołaja Fiodoro$\mathrm{wa}^{46}$, można doszukać się pewnych analogii do mitu wampirycznego. Filozof proponuje

zachowanie aktualnego życia ludzi w postaci nieśmiertelnej oraz wskrzeszenie zmarłych przodków z ich prochów poprzez wykorzystanie osiągnięć nauki i techniki. Jest to nieśmiertelność osiągana siłami wyłącznie ludzkimi i przy tym polegająca na zachowaniu człowieka takim, jakim on za życia jest, poprzez usunięcie defektu bytowego, którym jest śmierć ${ }^{47}$.

Wampiryzm oferuje podobne perspektywy - wskrzeszenie zmarłych, udoskonalenie istoty przemienionej poprzez wyrugowanie ułomności, brzydoty, słabości, a przede wszystkim śmiertelności.

\footnotetext{
${ }^{40}$ Z. Bauman, Śmierć i nieśmiertelność..., s. 46.

${ }^{41}$ Ibidem, s. 49.

42 Ibidem, s. 20.

43 A. Sawicki, Rosyjska immortologia ..., s. 10.

44 Ibidem, s. 9.

45 Ibidem.
}

${ }^{46}$ Proces wskrzeszania zmarłych w koncepcji Fiodorowa opiera się na naukowych metodach oraz wspólnej pracy wielu pokoleń zjednoczonego społeczeństwa. Jak pisze myśliciel: „Собирание рассеяных частиц есть вопрос космотеллургической науки и искусства, следовательно, мужское дело, а сложение уже собранных частиц есть вопрос физиологический, гистологический, вопрос сшивания, так сказать, тканей человеческого тела, тела своих отцов и матерей, есть женское дело; конечно, было бы странно, если физиологическая и гистологическая наука ограничивалась только живосечением и не могла бы перейти к восстановлению" - idem, Coчинения, Москва 1982, s. 419.

47 Ibidem, s. 12. 
Swoistą, choć tylko do pewnego stopnia, pochwałę wampiryzmu znajdujemy w powieści Julii Nabokowej VIP znaczy wampir (VIP значит вампир, 2008). Bohaterowie utworu przyjmują metamorfozę z radością. Jedna z protagonistek „благодарила вампира, подарившего ей десятилетия юности, чувственности и удовольствия" ${ }^{\text {"48. }}$. Oferta wampira — dar młodości, beztroski i przyjemności ma szczególne znaczenie nie tylko w świecie przedstawionym powieści, lecz także we współczesnej rzeczywistości. W obu tych przestrzeniach króluje glamour, a rzeczy brzydkie czy przykre

odsuwamy na taką odległość, z której ich odór czy nieprzyjemny widok będą nas mniej dotykać [...]. Przykre myśli muszą być stlumione. Jeśli to się nie uda, to trzeba je upiększyć lub zamaskować, by ich szpetny wygląd nie mógł nam już dokuczać ${ }^{49}$.

Ciągłość życia wyraża się w powieści Nabokowej w motywie powtarzalności i nowego początku. Wampiryczni bohaterowie są zmuszeni do ukrywania swojej natury, w związku z czym ich pobyt w jednym miejscu nie trwa dłużej niż dziesięć lat, po czym następuje nowy etap życia w nowej lokalizacji. Można to interpretować jako ponowne narodziny bez konieczności przeżywania dramatu śmierci:

В двадцатом веке она прожила двенадцать жизней в двенадцати городах, каждую - длиной от пяти до десяти лет. Она была дюжиной разных женщин - затворницей и искусительницей, звездой и серой мышью, авантюристкой и примерной налогоплательщицей ${ }^{50}$.

Cechą wampira jest nieskazitelność jego wyglądu. Istoty przemienione wyróżnia niezwykła fizyczna atrakcyjność („Теперь она выглядела моложе и красивее себя прежней" $\left.{ }^{\prime 51}\right)$. Mamy tu do czynienia z selektywnym przyznawaniem prawa do nieśmiertelności oraz regulacją liczebności środowiska nieumarłych. W omawianym utworze wampiry, zgodnie z przekazem zawartym w tytule, tworzą elitarną grupę. Przyjęcie do niej gwarantują szczególne przymioty lub talenty, którymi kandydat wykazuje się już na etapie ludzkiej egzystencji: „Ее красота, очарование юности, взрывной темперамент, природная грация и талант к перевоплощению стали для нее приговором и одновременно пропуском в новую жизнь" ${ }^{2}$. Podkreśla to hermetyczność powieściowej wampirycznej diaspory oraz iluzyjność marzenia o nieśmiertelności w przestrzeni fizycznej. Jest ona bowiem zarezerwowana dla nielicznych wybrańców, co jeszcze bardziej pobudza pragnienie nieosiągalnego. Jednocześnie Nabokowa akcentuje eksponowaną także przez autorów Braci krwi tęsknotę wampira za utraconym człowieczeństwem z jego przemijalnością i niedoskonałością, w których istota nieumarła dostrzega sens i urok bytu.

\footnotetext{
48 Ю. Набокова, VIP значит вампир, Москва 2010, s. 202.

49 Z. Bauman, Śmierć i nieśmiertelność..., s. 20.

50 Ю. Набокова, VIP значит вампир, s. 200.

51 Ibidem, s. 196.

52 Ibidem.
} 
Wampiry w ujęciu pisarki zachowują emocjonalną więź z utraconymi krewnymi i przyjaciółmi, choć nie mogą się z nimi kontaktować. Starzenie się i śmierć bliskich rzucają cień na beztroskę wampirycznego życia, przyczyniają się do zwielokrotnienia poczucia samotności: „В следующие пять лет знакомые ее юности умирали одна за другой. [...] Ее трясло, она чувствовала себя преступницей, обманувшей смерть. Смертельно старой преступницей” ${ }^{2}$. Egzystencjalne lęki wampira stanowią interesujące novum we współczesnym wariancie mitu wampirycznego i przyczyniają się do dalszych zmian w jego kreacji. Dlatego wampir z samotnika, potwora, ucieleśnienia śmierci staje się istotą społeczną, dbającą o przeżycie swoje i swojego otoczenia. O potrzebach współczesnego wampira świadczy wypowiedź jednego z bohaterów powieści VIP znaczy wampir: „Теперь ты понимаешь, почему вампиры держатся друг друга и живут большой дружной семьей? Надо же нам кого-то любить и кому-то радоваться" 54 .

Mit wampiryczny łączy dwa aspekty wpisane w odwieczne filozoficzne rozważania o naturze i predestynacji człowieka — śmierć i nieśmiertelność. $\mathrm{W}$ postaci wampira śmierć odbija się jak w wielopłaszczyznowym zwierciadle i pokazuje swoje różne oblicza. Istotę wampiryczną traktuje się jako ucieleśnienie śmierci i obraz jej ohydy. Jednocześnie jest ona jednak symbolicznym dowodem na możliwość przekroczenia granicy śmierci i spełnienia nadziei na nieśmiertelność. Bez wiary w nieśmiertelność życie staje się pozbawionym perspektyw łańcuchem biologicznych etapów, nieuchronnie prowadzących człowieka do ostatecznego unicestwienia. W pewien sposób zatem wampir odgrywa rolę wybawcy, niesie nadzieję, a „motywacja przemiany w wampira zyskuje tym samym szlachetny wymiar ratunku przed śmiercią" ${ }^{55}$.

\section{Bibliografia}

Bauman Z., Śmierć i nieśmiertelność. O wielości strategii życia, przeł. N. Leśniewski, Warszawa 1998.

Bradke M., Wstęp, [w:] Pokój na wieży. Opowieści wampiryczne, wyb. i oprac. M. Bradke, Wrocław-Warszawa-Kraków 1991.

Gorer G., Death, Grief and Mourning, New York 1965.

Janion M., Wampir. Biografia symboliczna, Gdańsk 2002.

Krzyk J., Porfiria. Skąd się biora wampiry?, „Gazeta Wyborcza” 17.11.2014, http://wyborcza.pl/ alehistoria/1,121681,16968029,Skad_sie_biora_wampiry_.html.

Ostrowska A., Śmierć i umieranie, Warszawa 1991.

Plancy J. C. de, Słownik wiedzy tajemnej, przeł. M. Karpowicz, Warszawa-Kraków 1993.

Pustkowski M., Lustracja wampira, „Polityka” 10.03.2007, http://www.polityka.pl/tygodnikpolityka/ nauka/212320,1,lustracja-wampira.read.

53 Ibidem, s. 202.
54 Ibidem, s. 215.
55 Е. Ковтун, Вампир без страха и упрека..., s. 45.

Slavica Wratislaviensia 167, 2018

(C) for this edition by CNS 
Roux J. P., Krew. Mity, symbole, rzeczywistość, przeł. M. Chrobak, Kraków 2013.

Sawicki A., Rosyjska immortologia. Śmierć i nieśmiertelność w poglądach myślicieli XVIII-XX wieku, Białystok-Kraków 2016.

Sznajderman M., Zaraza, Mitologia dżumy, cholery i AIDS, Warszawa 1994.

Thomas L. V., Trup. Od biologii do antropologii, przeł. K. Kocjan, Łódź 1991.

Thomas L. V., Tworzenie tanatologii, przeł. M.L. Kalinowski, [w:] Wymiary śmierci, wyb. i słowo wstępne S. Rosiek, Gdańsk 2010.

Vovelle M., Historia ludzi w zwierciadle śmierci, przeł. M. Ochab, [w:] Wymiary śmierci, wyb. i słowo wstępne S. Rosiek, Gdańsk 2010.

Vovelle M., Śmierć w cywilizacji Zachodu, przeł. M. Ochab, Gdańsk 2008.

Wolski M., Wampir: wiwisekcja. Wyobrażenia krwiopijców we wspótczesnej kulturze, Wrocław 2014.

Załoga M. T., Zachorować na Dracule, „Gazeta Wyborcza” 7.05.2002.

Дивов О., Ночной смотрящий, Москва 2008.

Ильин И., Сущность и особенность русской культуры, „Пространство и время” 2010, nr 1, http://space-time.ru/index.php/space-time/article/view/2226-7271provr_st1-1.2010.121/389.

Ковтун Е., Вампир без страха и упрека: новейшие модификации образа, [w:] Fantastyka rosyjska dawniej i dziś, red. A. Polak, wsp. I. Zawalska, Katowice 2013.

Набокова Ю., VIP значит вампир, Москва 2010.

Пехов А., Бычкова Е., Турчанинова Н., Кровные братья, Москва 2011.

Радищев А., О человеке, его смертности и бессмертии, [w:] idem, Сочинения, Москва 1988, http://ruslit.traumlibrary.net/book/radischev-sochinenia/radischev-sochinenia.html\#work005.

Русская философия. Энциклопедия, red. М. Маслин, Москва 2007.

Толстой А., Семья вурдалака, http://detectivebooks.ru/book/6563755/?page=6.

Федоров Н., Сочинения, Москва 1982.

\section{Death and immortality - two aspects of vampire myth (based on Russian literature)}

\section{Summary}

This article provides an opinion about death and immortality in culture and philosophy and the connection between these motives and vampire novels. The article shows many of symbolic aspects of the vampire. In the novels of different ages vampire was a synonym of death fear, death victim, friend and even rescuer on the existence way of a human being. The question based on selected Russian vampire novels.

Keywords: vampire, death, immortality, culture, Russian literature 


\section{Смерть и бессмертие - два аспекта вампирического мифа (на основе русской литературы)}

Статья содержит обзор мнений на тему смерти и бессмертия в культуре и философии в контексте связей этих мотивов с вампирическим текстом. В статье представлена многоаспектность символики вампира, который в текстах разных эпох является, с одной стороны, олицетворением страха перед смертью и усопшими, с другой - жертвой смерти. Данная проблема рассматривается на основе избранных примеров русских вампирических романов.

Ключевые слова: вампир, смерть, бессмертие, культура, русская литература 